\title{
The 1999 Massry Prize in Nephrology, Physiology and Related Fields Goes to Professor Günter Blobel of the Rockefeller University, New York, N.Y.
}

Proteins are the large molecules that give our bodies form and structure. At the level of a cell, they are the molecules that form the highly defined structures we observe in the microscope, that are responsible for cell motility, that form the connections between our senses and our consciousness, and that are responsible for contracting the beating cells of our hearts. There are a multitude of different proteins in a cell, each assigned a role and its place in the three-dimensional architecture. Similarly, an abundance of other proteins are secreted from cells to serve their functions in the blood plasma or as hormone molecules delivering information to distant tissues. But how are all these proteins directed to go to the correct locations within a cell, how is it decided which proteins will be secreted into the bloodstream and which not? What mechanisms play the role of traffic police?

Günter Blobel has been one of the world's leading biologists for more than three decades and his contributions to understanding these mechanisms, more than those of any other scientist, have revealed an ordered set of chemical rules for protein trafficking that has made sense from apparent chaos. His work has reduced cell biology to chemistry. Starting in the 1960s, he discovered the presence of specific signals on proteins destined to be secreted and, in an enormous leap, was able to reconstitute those actions in a test tube, thus reducing the problem into solvable components. And it was he who indeed unraveled the ways in which such proteins are processed and packaged, and discovered the details of the machines on the intracellular assembly line that do this work. His subsequent work opened the door to the study of other mechanisms by which other proteins are directed to the nucleus of a cell or to the intracellular energy factories, the mitochondria. His use of complementary biochemical, biophysical, structural and genetic approaches has set the standard for this highest traditions that exemplify modern cellular biology. He has the extraordinary ability to identify and conceptualize the key problems in the areas he is studying and at the same time carry out ground-breaking studies. His persistence in elucidating these key mechanisms has created a body of achievement that continues to yield unexpected new insights on how protein trafficking is managed. His insights have led to major contributions to life and health, from the development of drugs to control the secretion of hormones to the understanding of disordered protein trafficking involved in diseases such as cystic fibrosis. Thus, his discoveries have far-reaching implications for every aspect of life and health.

Professor Blobel is the fourth recipient of the Massry Prize. Two months after his selection for the Massry Prize, he received the 1999 Nobel Prize in Physiology and Medicine.

Shaul G. Massry, MD

President of the Meira and Shaul G. Massry Foundation Los Angeles, Calif.

\section{KARGER}

() 1999 S. Karger AG, Basel

Fax +41613061234

E-Mail karger@karger.ch www. karger.com
Accessible online at: www.karger.com/journals/ajn 